\title{
Knowledge, attitude and practice regarding emergency contraceptives among married women of urban slum area
}

\author{
Vivek R. Raikar ${ }^{1}$, Pallavi A. Potdar ${ }^{2 *}$, Ashutosh B. Potdar ${ }^{3}$ \\ ${ }^{1}$ Department of OBGY, ${ }^{2}$ Department of Community Medicine, ${ }^{3}$ Department of Forensic Medicine, Aarupadai Veedu \\ Medical College, Kirumampakkam, Puducherry, India
}

Received: 05 May 2015

Accepted: 06 June 2015

*Correspondence:

Dr. Pallavi A. Potdar,

E-mail: pallupot@gmail.com

Copyright: $\odot$ the author(s), publisher and licensee Medip Academy. This is an open-access article distributed under the terms of the Creative Commons Attribution Non-Commercial License, which permits unrestricted non-commercial use, distribution, and reproduction in any medium, provided the original work is properly cited.

\begin{abstract}
Background: Unprotected sexual intercourse \& contraceptive failure lead to unintended pregnancies \& unsafe abortions. Emergency contraceptives offer safe \& effective emergency care intervention. The objective was to assess the knowledge, attitude \& practice regarding emergency contraceptives among married women of reproductive age group and to study the influence of educational status on the awareness \& willingness to use emergency contraceptives.

Methods: Community based cross-sectional study was conducted from 1st May 2011- 30th Jan 2012 in 286 married women in age group 15-45 yrs residing in the field practice area of Urban Health Centre attached to Department of Community Medicine, Bagalkot, Karnataka. Data was collected by personal interview method with house-to-house visit by administering structured, pre-tested questionnaire to elicit information on knowledge, attitude \& practice regarding emergency contraceptives. Chi square test was used to estimate statistical significant differences.

Results: Out of total 286 females, majority were in the age group of $20-30 \mathrm{yrs}, 94.40 \%$ were Hindus, majority i.e. $81.74 \%$ were homemakers \& $59.79 \%$ were illiterate, $72.48 \%$ belonged to lower social class (class IV \& V) according to modified B.G. Prasad classification. We found that $56 \%$ women had accepted one or other contraceptives. Only $12 \%$ women were aware about EC while among literates, $29 \%$ were aware about EC out of which only $4.38 \%$ had idea about the correct dosage, availability and side effects of the pills. Willingness to use EC was seen among $29 \%$ of women out of which majority i.e. $54.78 \%$ were literate and $68.32 \%$ were employed. Among the study population $3 \%$ of the women actually practiced emergency contraceptives. Educational status of females had significant association with awareness about EC pill $(\chi 2=29.46)$ and positive attitude towards usage of EC pill $(\chi 2=27.32)$.

Conclusion: The awareness as well as the usage of emergency contraceptives is very low in our society. Still we are facing the problem of illiteracy in our country which is predominant in slum areas. More emphasis should be given to female education and empowerment in order to make them capable of taking decisions regarding their own reproductive health.
\end{abstract}

Keywords: Emergency Contraceptives, Urban Slum, Knowledge, Attitude, Practice

\section{INTRODUCTION}

Emergency contraception is indicated after unprotected sexual intercourse, following sexual abuse, misuse or non-use of contraception. Emergency contraception plays a vital role in preventing unintended pregnancy if applied correctly, it helps to reduce unintended childbearing and unsafe abortion, which are the major problems affecting maternal health. ${ }^{1}$

Unintended pregnancy poses a major challenge to the reproductive health of young women in developing countries. Some young women with unintended pregnancies undergo abortions, many of which are 
performed in unsafe conditions while others carry their pregnancies to term, incurring risks of morbidity and mortality higher than those for adult women. ${ }^{2}$ In India a sizeable population of pregnancies are either unplanned or unwanted and thus these pregnancies add to the population burden or the women may resort to pregnancy termination by traditional or harmful methods leading to serious health consequences. Annually 11 million abortions occur in India, majority being illegal and unsafe, killing almost 20,000 women. Though numerous contraceptive techniques are available and there has been a steady increase in contraceptive prevalence rate, there are a large number of unplanned or unwanted pregnancies either due to regular contraceptive failure or use of incorrect method. Emergency Contraception is a safe and effective method of preventing these unwanted pregnancies following failure of contraception or unprotected sexual exposure. ${ }^{3}$

Keeping in view the above points the study was undertaken to assess the knowledge, attitude \& practice regarding emergency contraceptives among married women of reproductive age group \& to study the influence of educational status on the awareness \& willingness to use emergency contraceptives.

\section{METHODS}

Community based cross-sectional study was conducted from $1^{\text {st }}$ May 2011- 30 $0^{\text {th }}$ Jan 2012 in the field practice area of Urban Health Centre attached to Department of Community Medicine, Bagalkot, Karnataka. Urban health centre caters a population of 8530 . The area has got four blocks out of which one was randomly selected; it has population of 2840 . The list of all 286 eligible couples in this area was obtained from the register maintained by urban health centre. Approval from the institutional ethical committee was obtained. The subjects were explained about the purpose of study $\&$ assured that the information will be utilized only for research purpose. Data was collected by house to house visit by interview method by administering a pre-designed, semistructured questionnaire after ensuring verbal informed consent. Information was collected regarding age, level of education, occupation, religion, type of family, per-capita income and current use of contraception, history of unwanted pregnancy as well as knowledge, attitude and practice of emergency contraceptives was meticulously enquired after taking the women into complete confidence.

\section{Statistical analysis}

Data were analysed using SPSS statistical package version 20. Chi square test was used to estimate statistical significant differences.

\section{RESULTS}

The mean age of study participants was 28 years (Range 15-45 years). Out of the total 286 study participants, $59 \%$ were illiterate which is higher compared to the National literacy rate. Only $33(12 \%)$ had knowledge about emergency contraceptives and among the illiterates no one was aware about EC. Awareness about EC is more among literates than illiterates \& this observation is statistically significant $(\chi 2=29.46)$ (Table 1$)$.

Table 1 Educational status \& awareness about EC among the study participants.

\begin{tabular}{|llllll|}
\hline \multirow{2}{*}{ Education } & \multicolumn{2}{c}{ Aware of EC } & \multicolumn{2}{l|}{ Unaware of } \\
& No & $\mathbf{( \% )}$ & No & $\mathbf{( \% )}$ & Total \\
\hline Illiterate & 0 & 0 & 171 & 100 & 171 \\
\hline Literate & 33 & 29 & 82 & 71 & 115 \\
\hline Total & 33 & 12 & 253 & 88 & 286 \\
\hline
\end{tabular}

$\chi 2=29.46, p<0.001$ at d.f. 1 after Yates Correction

When we analyzed relation between level of education \& awareness regarding EC, we found that awareness is significantly more among females who were better educated than others and this difference was statistically significant. $(\chi 2=44.48, \mathrm{p}<0.001)($ Table 2$)$.

Table 2: Level of education and awareness about emergency contraceptives among study participants.

\begin{tabular}{|c|c|c|c|c|c|}
\hline \multirow[t]{2}{*}{ Education } & \multicolumn{2}{|c|}{$\begin{array}{l}\text { Aware of } \\
\text { EC }\end{array}$} & \multicolumn{2}{|c|}{$\begin{array}{l}\text { Unaware } \\
\text { of EC }\end{array}$} & \multirow[t]{2}{*}{ Total } \\
\hline & No & $\%$ & No & $\%$ & \\
\hline Illiterate & 0 & 0 & 171 & 100 & 171 \\
\hline Primary school & 7 & 17 & 32 & 83 & 39 \\
\hline High school & 6 & 23 & 20 & 77 & 26 \\
\hline Pre-university & 9 & 28 & 23 & 82 & 32 \\
\hline Degree & 11 & 61 & 7 & 39 & 18 \\
\hline Total & 33 & 12 & 253 & 88 & 286 \\
\hline
\end{tabular}

$\chi 2=44.48, \mathrm{p}<0.001$

In our study, among the women who had knowledge about EC, $48.7 \%$ were aware of brand name, $29.4 \%$ knew about the exact dosage.

Educational status of the females has got positive impact on the willingness to use EC which is statistically significant $(\chi 2=27.32)$ (Table 3$)$. In our study only $3 \%$ women actually practiced EC in their life. (Figure 1).

Table 3: Educational status \& willingness to use EC.

\begin{tabular}{|llllll|}
\hline \multirow{2}{*}{ Education } & \multicolumn{2}{l}{ Willing to } & \multicolumn{2}{l}{ Not willing to } \\
& use EC & \multicolumn{2}{l|}{ use EC } & Total \\
\cline { 2 - 6 } & No & \% & No & \% & \\
\hline Literate & 63 & 54.78 & 52 & 45.22 & 115 \\
\hline Illiterate & 19 & 11.11 & 152 & 88.89 & 171 \\
\hline Total & 82 & 28.67 & 204 & 71.33 & 286 \\
\hline
\end{tabular}

$\chi 2=27.32$ at d.f. $1, \mathrm{p}<0.001$ 


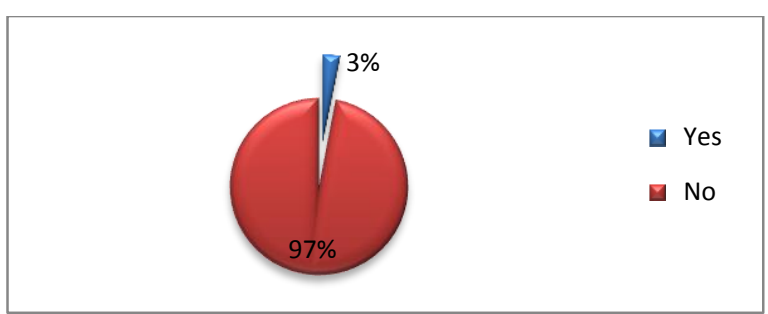

Figure 1: Use of emergency contraceptives among the study population.

When we studied the source of knowledge about the emergency contraception, we found that majority of women i.e. $59.4 \%$ derived knowledge from mass media like TV, Radio followed by $25.4 \%$ from health workers which includes our urban health centre and anganwadi workers, $19.5 \%$ from doctor \& $17.8 \%$ from husband/ friends/neighbours (Table 5).

\section{Table 5: Source of information about the emergency contraceptives.}

\begin{tabular}{|ll|}
\hline Source of information & Percentage \\
\hline Mass media & 59.4 \\
\hline Newspapers & 8.1 \\
\hline Health worker & 25.4 \\
\hline Doctor & 19.5 \\
\hline Husband /friends/neighbours & 17.8 \\
\hline
\end{tabular}

\section{DISCUSSION}

Emergency contraception will definitely help to reduce unintended pregnancies as well as its consequences like induced abortions, complications which may arise during or after unsafe abortions etc. EC is also very useful option when there is failure of barrier methods. It's important for a woman to have correct knowledge about EC like when to use, its availability, correct dosage. Educated women can take the decisions regarding their family size, which family planning method to use, timing of pregnancy as the awareness regarding contraception is higher among educated women. Hence this study was undertaken to know the knowledge, attitude \& practice regarding EC among married women of urban slum area.

Various similar studies have been conducted in different places in India as well as in abroad. Similar study done in urban slum area in Raichur, Karnataka ${ }^{4}$ revealed that $13.4 \%$ of the women were aware about EC which is similar to our study findings, another study conducted in Vijapur, Karnataka in urban slum community observed that $4 \%$ women had correct knowledge about $\mathrm{EC}^{5}$ and study done at Lucknow, Uttar Pradesh found that only $2 \%$ of the women had some knowledge about $\mathrm{EC}^{6} \&$ study in Chandigarh, only $1 \%$ of the women knew about EC. ${ }^{7}$ which is much less than our findings. According to findings of a study conducted at New Delhi none of the study participants knew about EC. ${ }^{8}$ The analysis of data from DLHS-3 (2005) for four southern states revealed that Kerala recorded highest i.e 70\% awareness among women followed by Tamil Nadu (50\%), Karnataka (47\%), \& lastly Andhra Pradesh (20\%). ${ }^{9}$ According to NFHS-III, knowledge about EC is $11 \%$ in women which is similar to our findings. Study done at Uttarakhand revealed that $20 \%$ of the women had complete knowledge about $\mathrm{EC}^{3}$, similar study in South Africa revealed $17 \%$ awareness among their study population ${ }^{10}$, while study done at Jamaica revealed $84 \%$ awareness ${ }^{11}$ \& in Egypt $^{1}$ it was $25 \%$, while in Mexico it was $83 \%{ }^{12} \&$ in Hong Kong $67 \%$ of the women heard about $\mathrm{EC}^{13}$. Similar findings were also given by a study done among educated working women in Chandigarh, revealed education has a positive impact on the awareness about EC. ${ }^{14}$

The study done at Uttarakhand revealed that knowledge about the EC is more among the educated females which was statistically significant which is similar to our findings. ${ }^{3}$ The study done at Raichur found that, only 11 (13.4\%) literate women who had either secondary education or graduates were aware about emergency contraception. ${ }^{4}$ Similar findings were also observed in study done in Kerala showing that, the level of education has a positive impact on the knowledge regarding EC. ${ }^{15}$ The analysis of DLHS(2005) data revealed that, the level of education has positive impact on the better knowledge as well as acceptance of EC among the women from all the four Southern states i.e. Karnataka, Kerala, Andhra Pradesh \& Tamil Nadu. ${ }^{9}$

Similar findings were also given by study in Uttarakhand. ${ }^{3}$ Similar study in Gorakhpur found that $5 \%$ of the study population intended to use EC, ${ }^{16}$ while study done in Egypt observed that there no significant difference between knowledge of EC \& education contradicting our findings. ${ }^{1}$

The study done at Jamaica revealed $10 \%$ of the people practiced EC in their life. ${ }^{11}$ similar findings were also observed in study at Hong $\mathrm{Kong}^{13}$ while it was $20.5 \%$ according to findings in Egypt. ${ }^{1}$ Study in Uttarakhand found that $7 \%$ women had actually practiced EC. ${ }^{3}$ Another studies done at Gorakhapur ${ }^{16} \&$ Bhopal $^{17}$ found that none of the study participants practiced EC while study done at Maharashtra observed that $0.1 \%$ of women used EC. ${ }^{18}$ According to DLHS-3 (2007-08) ${ }^{19}$ in Karnataka, $1 \%$ of the women from urban area used EC which is little less as compared to our findings.

The study conducted in Vijapur, Karnataka observed that mass media $15.3 \%$ was major source of information followed by health facility $12.6 \%$ \& family, friends $10 \% .^{5}$ Similar findings were given by study conducted in Nagpur, Maharashtra ${ }^{18}$ showing that majority i.e. $65 \%$ of the participants got the knowledge from mass media while a study done at Karachi revealed that $50 \%$ of the women who had knowledge about EC was from doctor \& $20 \%$ from family members, $15 \%$ from magazines, ${ }^{20}$ while study done at Egypt revealed that majority of the women i.e. $28 \%$ got the knowledge from doctor or hospital staff while from mass media it was $15.9 \% .^{1}$ 
Another study conducted in Pondicherry observed that, knowledge \& usage about EC was $11.5 \%$ \& $10.5 \%$ respectively and source of information regarding EC was doctors $(73.9 \%)$, TV $(65.2 \%) \&$ friends and relatives $(52 \%) .^{21}$

\section{CONCLUSION}

The study revealed that awareness about emergency contraceptives is very low among the study population. There is urgent need for dissemination of information regarding proper use of EC in the society.

Funding: No funding sources

Conflict of interest: None declared

Ethical approval: The study was approved by the Institutional Ethics Committee

\section{REFERENCES}

1. EI Sabaa HA, Ibrahim FA, Hassan WA. Awareness and use of emergency contraception among women of Childbearing age at the family health care centers in Alexandria, Egypt. Journal of Taibah University Medical Sciences. 2013;8(3):167-72.

2. Aziken ME, Okonta PI, Ande ABA. Knowledge \& perception of emergency contraception among female Nigerian undergraduates. International Family Planning Perspectives. 2003;29(2):84-7.

3. Awasthi S, Rawat CMS, Jha S, Mehra JS, Bartwal J. Evaluation of emergency contraceptive use among reproductive women in Nainital District of Uttarakhand India. Indian J of Maternal \& Child Health. 2013;15(2).

4. Ade AD, Patil R. Contraceptive practices and awareness of emergency contraception among Muslim women of urban slum of Raichur, Karnataka. IJRCOG. 2014;3(1):70-4.

5. Biradar SM. Survey of knowledge and perceptions towards emergency contraceptives among women of Bijapur, South India. IJPBS. 2013;4(1):583-7.

6. Nigam A, Maheshwari N, Prakash A. Knowledge of emergency contraception and contraceptive practices: Representative study from rural Uttar Pradesh. Indian Journal of Community Medicine. 2010;35(3):449-50.

7. Mehra R, Goel P, Dua D, Huria A. Knowledge of emergency contraception among women coming for induced abortion. J Obstet Gynaecol India. 2006;56(3):233-5.

8. Tripathi R, Rathore AM, Sachdev J. Emergency contraception: Knowledge, attitude and practice among health care providers in North India. J Obstet Gynaecol Res. 2003;29(2):142-6.

9. Murthy MSR. Knowledge of Emergency contraception in the Southern states of India. Ethno Med. 2014;8(3):277-83.
10. Mqhayi MM, Smit JA, McFadyen ML. Missed opportunities: emergency contraception utilization by young South African women. Afr J Reprod Health. 2004;8:137-44.

11. Sorhaindo A, Becker D, Fletcher H. Emergency contraception among university students in Kingston, Jamaica: a survey of knowledge, attitudes and practices. Contraception. 2002;66:261-8.

12. Heimburger A, Acevedo-Garcia D, Schavon R. Emergency contraception in Mexico City: knowledge, attitude and practices among providers and potential clients after a 3-year introduction effort. Contraception. 2002;66:321-9.

13. Lee SWH, Wai MFY, Lai LYH, Ho PC. Women's Knowledge of and attitudes towards emergency contraception in Hong Kong: questionnaire Survey. HKMJ. 1999;5(4):349-52.

14. Takkar N, Goel P, Saha P.K., Dua D. Contraceptive Practices and Awareness of Emergency Contraception in Educated Working Women. Indian J Med Sci. 2005;59(4):143-9.

15. Murthy MSR. Determinants of knowledge of emergency contraception in socially \& economically developed states of India: A study of Kerala \& Punjab. International J Science \& Research. www.ijsr.net.

16. Reena S, Dhirendra Kumar S, Radha S. Contraceptive knowledge, attitude and practice (KAP) study. J Obstet Gynecol India. 2005; 55(6):546-50.

17. Bhadra SC, Tiwari S, Kakkar RN. KAP on Emergency Contraception among Medical \& General Community of Bhopal city. Indian Journal of Community Medicine. 2005;30(4).

18. Relwani N, Saoji A, Kasturwar NB, Nayse J, Junaid M, Dhatrak. Emergency contraception: Exploring the knowledge, attitude \& practices of engineering college girls in Nagpur district of central India. National Journal of Community Medicine. 2012;3(1):14-9.

19. India Ministry of Health \& Family Welfare. District level household \& facility survey-3(DLHS-3) 200708 Factsheet for Karnataka. International institute for Population Sciences, Mumbai; 8p.

20. Irfan F, Karim SI, Hashmi S, Ali S, Ali SA. Knowledge of emergency contraception among women of childbearing age at a teaching hospital of Karachi. Journal of the Pakistan Medical Association. 2009;59(4):235-40.

21. Lakkawar NJ, Magon S, Alaganandam $P$. Assessment of attitude towards use of emergency contraceptives among antenatal women. IJRCOG. 2014;3(4):1067-72 .

Cite this article as: Raikar VR, Potdar PA, Potdar AB. Knowledge, attitude and practice regarding emergency contraceptives among married women of urban slum area. Int J Reprod Contracept Obstet Gynecol 2015;4:1008-11. 